\title{
Hubungan Persepsi dengan Perilaku Ibu Membawa Balita ke Posyandu
}

\author{
Dian Palupi Kusuma Wardani, Sheizi Prista Sari, Ikeu Nurhidayah \\ Fakultas Keperawatan Universitas Padjadjaran \\ E-mail:ngkeu_mail@yahoo.com
}

\begin{abstract}
Abstrak
Posyandu merupakan pusat pemantauan tumbuh kembang balita berbasis masyarakat, namun masih banyak ibu yang tidak membawa anak berkunjung teratur ke posyandu. Di Kabupaten Bandung, Posyandu Desa Cimekar memiliki angka kunjungan balita yang terendah yaitu 70,3\% pada Bulan Oktober- Desember 2013. Tujuan penelitian ini untuk mengetahui hubungan antara persepsi ibu dengan perilaku membawa balita ke posyandu dengan pendekatan teori Health Belief Model. Penelitian ini menggunakan metode deskriptif kuantitatif dengan pendekatan cross sectional. Sampel penelitian berjumlah 94 ibu balita yang diambil dengan menggunakan teknik simple random sampling di 10 Posyandu Desa Cimekar. Analisis menggunakan chisquare. Hasil penelitian menunjukkan bahwa 52,12\% memiliki persepsi positif tentang posyandu dan 59,57\% responden memiliki perilaku rutin membawa balita ke posyandu. Hasil analisis bivariat menunjukkan terdapat hubungan antara persepsi dengan perilaku ibu membawa balita ke posyandu (nilai $p=0,000 ; \alpha=0,05$ ). Simpulan dari penelitian ini menunjukkan bahwa persepsi ibu tentang posyandu belum merata dengan baik. Hasil penelitian ini merekomendasikan agar puskesmas memberikan pembinaan terhadap para ibu balita bukan hanya penyuluhan, namun diberikan pengarahan dan bimbingan tentang pentingnya membawa balita ke posyandu.
\end{abstract}

Kata kunci: Balita, Health Belief Model, perilaku, persepsi, posyandu.

\section{The Relationship between Mother's Perception and Behavior on Attending Posyandu}

\begin{abstract}
Community health post as well known as posyandu provide as center to monitor growth in children under five years old. Data showed that the number of mother's attendance behavior to Posyandu in Cimekar's Village was very low, only 70.5\% from October to December 2013. The aimed of this study was to identify the relationship between mother's perception and parents behavior on taking their children to posyandu based on Health Belief Model Theory. The method of this study was descriptive with cross sectional study. Simple random sampling was used as sampling technique with 97 mothers who has child under five years old among 10 Posyandu in Cimekar was taken in this study. Data was analyzed by chi-square. The result of this study showed that there was significant relationship between mother's perception and mother's behavior to attend Posyandu $(p=0.000 ; \alpha=0.05)$. Data showed that $52.25 \%$ respondents had a positive perception about posyandu and 59.5\% respondents had positive behavior to take their child to posyandu. The recommendation for Puskesmas is to give further information and motivation to mother to attend posyandu frequently.
\end{abstract}

Key words: Behavior, child under five years old, Health Belief Model, perception, posyandu. 
Dian Palupi Kusuma Wardani: Hubungan Persepsi dengan Perilaku Ibu

\section{Pendahuluan}

Saat ini angka kematian balita (AKABA) di Indonesia telah mengalami penurunan lebih dari setengah dalam periode 19902013 (UNICEF, 2014). Penurunan angka kematian balita terjadi dari 84 kematian per 1000 kelahiran hidup menjadi 29 per 1000 kelahiran hidup. Namun demikian, angka ini masih cukup tinggi dari target penurunan angka kematian balita menurut Millenium Development Goals (MDGs), yaitu 23 per 1000 kelahiran hidup pada tahun 2015 (Bappenas, 2014).

Peningkatan derajat kesehatan dalam mengurangi AKABA dilakukan dengan upaya pemantauan status nutrisi, penyakit infeksi dan tumbuh kembang balita, serta peningkatan cakupan imunisasi dasar pada balita. Berdasarkan data Kemenkes RI (2012), menunjukkan bahwa cakupan imunisasi campak hanya 74\% dan imunisasi DPT-HB3 hanya $62 \%$ dari target nasional diatas $80 \%$. Selain itu, angka kesakitan akibat penyakit infeksi (ISPA/pneumonia dan tuberkulosis) masih tinggi pada balita. Salah satu upaya untuk mencegah angka kesakitan dan angka kematian anak balita adalah dengan melakukan pemeliharaan kesehatannya. Pemeliharaan kesehatan dititikberatkan dengan upaya pencegahan dan peningkatan kesehatan yang dapat dilakukan di Posyandu (Farida, 2012).

Posyandu dipandang sangat bermanfaat bagi masyarakat, akan tetapi keberadaannya di masyarakat kurang berjalan dengan baik, sehingga pemerintah mengadakan program revitalisasi Posyandu (Notoatmodjo, 2007). Sasaran kegiatan revitalisasi Posyandu ini adalah seluruh Posyandu dengan prioritas utama pada Posyandu Pratama dan Madya.

Kunjungan balita di Posyandu berkaitan dengan peran ibu sebagai orang yang paling bertanggungjawab terhadap kesehatan balita, karena balita sangat bergantung pada ibu. Alasan utama ibu membawa balita ke Posyandu karena ingin anak mendapatkan pelayanan kesehatan yang maksimal. Oleh karena itu, motivasi ibu dalam pemanfaatan Posyandu balita mempunyai andil yang besar dalam meningkatkan kesehatan balitanya (Farida, 2012).

Sikap ibu balita untuk menyadari bahwa
Posyandu merupakan hal penting yang dapat meningkatkan derajat kesehatan balita, akan menimbulkan perilaku positif ibu untuk hadir ke Posyandu membawa balita. Perilaku adalah bentuk respon atau reaksi stimulus atau rangsangan dari luar dan stimulus tersebut dapat diberikan dengan cara mengadakan penyuluhan-penyuluhan tentang Posyandu kepada lapisan masyarakat. Namun, dalam memberikan respon atau stimulus sangat tergantung pada karekteristik atau faktor-faktor lain dari orang bersangkutan yaitu faktor internal dan faktor eksternal (Rachmania, 2010). Apabila persepsi ibu balita tentang Posyandu positif, maka ibu balita akan hadir secara rutin ke Posyandu setiap bulannya dan sebaliknya, jika persepsi ibu balita tentang Posyandu negatif, maka kehadiran ibu balita tidak akan rutin setiap bulannya. Hal ini berarti meskipun stimulus sama bagi beberapa orang, namun respon setiap orang berbeda (Notoatmodjo, 2007). Sebaliknya, kesadaran ibu yang kurang akan pentingnya peran Posyandu menyebabkan terhambatnya proses pelayanan kesehatan yang baik bagi para balita (Trihono, 2005).

Beberapa penelitian menunjukkan terdapat hubungan antara persepsi seseorang (berdasarkan teori Health Belief Model) dengan perilaku pencegahan suatu penyakit. Hal ini diperkuat oleh hasil dari beberapa penelitian tersebut yang menunjukkan adanya hubungan antara persepsi seseorang dengan niatan untuk berperilaku mencegah suatu penyakit berdasarkan teori Health Belief Model. Seperti pada penelitian yang dilakukan oleh Sirait dan Sarumpaet (2012), tentang hubungan komponen Health Belief Model dengan penggunaan kondom pada Anak Buah Kapal (ABK) di Pelabuhan Belawan, menunjukkan terdapat hubungan yang signifikan antara persepsi keseriusan HIV/ AIDS dengan perilaku penggunaan kondom. Individu memersepsikan bahwa penyakit yang dialami semakin memburuk, mereka akan merasakan hal tersebut sebagai ancaman dan mengambil tindakan preventif. Hal ini sesuai dengan teori Health Belief Model yang menunjukkan bahwa persepsi seseorang akan memengaruhi tindakan seseorang.

Di Kabupaten Bandung, saat ini masih ditemukan kasus balita gizi buruk sebesar 
Dian Palupi Kusuma Wardani: Hubungan Persepsi dengan Perilaku Ibu

0,94\% dan cakupan kunjungan balita ke Posyandu hanya 64,6\% (Dinas Kesehatan Kabupaten Bandung, 2013). Puskesmas Cinunuk merupakan salah satu Puskesmas di Kabupaten Bandung yang memiliki Posyandu mandiri paling sedikit tiga Posyandu dari 90 Posyandu (3,33\%). Posyandu yang berstatus pratama sebanyak 15 Posyandu, madya 45 Posyandu, dan purnama 27 Posyandu (Dinas Kesehatan Kabupaten Bandung, 2013).

Berdasarkan data laporan bulanan Puskesmas Cinunuk Kabupaten Bandung pada Bulan Oktober-Desember tahun 2013, menunjukkan bahwa kunjungan balita dalam kegiatan Posyandu di wilayah kerja Puskesmas Cinunuk sebesar 74,5\% dan masih belum mencapai target kunjungan sebesar $85 \%$, dan hanya $1,4 \%$ yang memanfaatkan fasilitas layanan kesehatan yang lain, seperti ke dokter, bidan, maupun fasilitas pelayanan kesehatan yang lain (Laporan Puskesmas Cinunuk, 2013).

Wilayah kerja Puskesmas Cinunuk mencakup dua desa, yaitu Desa Cinunuk dan Cimekar. Hasil survei menunjukan bahwa di Desa Cimekar angka kunjungan balita ke Posyandu lebih kecil (70,3\%) dibandingkan Desa Cinunuk $(78,4 \%)$. Rata-rata cakupan kunjungan dan pemantauan pertumbuhan balita di Posyandu di Desa Cimekar wilayah kerja Puskesmas Cinunuk belum memenuhi target gizi puskesmas dan Standar Pelayanan Minimal (SPM) bidang kesehatan yang telah ditetapkan oleh Menteri Kesehatan berdasarkan KEPMENKES No. 1457/ MENKES/SK/2003 (Laporan Puskesmas Cinunuk, 2013).

Berdasarkan hasil studi pendahuluan ke beberapa Posyandu yang berada di Desa Cimekar, didapatkan bahwa masih banyak ibu yang tidak membawa balita ke Posyandu. Dari hasil obeservasi peneliti ke beberapa Posyandu di Desa Cimekar, ditemukan bahwa masih terdapat Posyandu yang belum menjalankan sistem 5 meja, hal ini dikarenakan peran dan jumlah kader Posyandu yang masih belum optimal. Selain itu, hanya beberapa Posyandu yang mempunyai bangunan sendiri dan fasilitas yang tersedia di Posyandu tersebut belum memadai. Namun, pelayanan yang diberikan Posyandu sudah mencukupi pelayanan minimal.
Hasil wawancara kepada kader kesehatan di Desa Cimekar, didapatkan bahwa beberapa kader sudah berupaya semaksimal mungkin untuk mengajak ibu balita untuk membawa balita ke Posyandu. Kader juga mendatangi rumah ibu yang tidak hadir dalam kegiatan Posyandu, dan bidan desa juga sudah berupaya untuk memotivasi ibu balita agar mau membawa balita ke Posyandu dengan rutin. Dari 31 Posyandu yang ada di Desa Cimekar, hanya tujuh Posyandu saja yang mencapai target SPM.

Peneliti juga melakukan wawancara kepada sepuluh orang ibu mengenai rutinitas ibu membawa balita ke Posyandu setiap bulan. Hasil wawancara menunjukkan bahwa dari sepuluh ibu hanya terdapat empat ibu saja yang rutin membawa anak ke Posyandu. Ratarata alasan ibu tidak membawa balitanya ke Posyandu karena rutinitas pekerjaan rumah yang bagi mereka tidak dapat ditinggalkan, menganggap bahwa Posyandu itu hanya menimbang saja, rasa malas untuk datang ke Posyandu, dan ada yang menganggap bahwa imunisasi itu haram sehingga hal ini menjadikan paradigma negatif tentang Posyandu.

Oleh karenaitu, peneliti memandang sangat penting untuk mengetahui persepsi individu mengenai suatu masalah dan bagaimana individu tersebut mengaplikasikannya dalam perilaku pencegahan guna memaksimalkan upaya preventif dari peningkatan kejadian suatu penyakit yang mungkin terjadi pada balita. Tujuan penelitian ini adalah untuk mengidentifikasi hubungan persepsi dengan perilaku ibu membawa balita ke Posyandu di Desa Cimekar wilayah kerja Puskesmas Cinunuk.

\section{Metode Penelitian}

Jenis penelitian yang digunakan yaitu deskriptif kuantitatif dengan menggunakan pendekatan cross sectional. Variabel independen pada penelitian ini adalah persepsi ibu mengenai Posyandu. Variabel dependen pada penelitian ini adalah perilaku ibu membawa balita ke Posyandu. Populasi dalam penelitian ini adalah ibu yang mempunyai balita di Desa Cimekar sebanyak 1.461 ibu balita. Sampel dalam penelitian 
Dian Palupi Kusuma Wardani: Hubungan Persepsi dengan Perilaku Ibu

ini adalah 94 ibu dengan balita yang diambil menggunakan simple random sampling.

Alat pengumpul data untuk mengukur persepsi ibu adalah kuesioner berdasarkan teori Health Belief Model, sedangkan untuk mengukur perilaku ibu membawa balita ke Posyandu menggunakan kuesioner dan Kartu Menuju Sehat (KMS). Kuesioner persepsi dan perilaku ibu sudah dilakukan uji reliabilitas, dengan nilai cronbach alpha sebesar 0,571; lebih besar dari r tabel $(0,444)$ sehingga semua item dinyatakan reliabel.

\section{Hasil Penelitian}

Berdasarkan hasil penelitian diperoleh informasi bahwa 52,12\% ibu memiliki persepsi positif dalam membawa balita ke posyandu dan 47,88\% ibu memiliki persepsi negatif dalam membawa balita ke posyandu (tabel 1).

Tabel 1 Distribusi Frekuensi Persepsi Ibu terhadap Perilaku Membawa Balita ke Posyandu $(\mathrm{N}=94)$

\begin{tabular}{lcc}
\hline $\begin{array}{c}\text { Persepsi Ibu tentang } \\
\text { Membawa Balita ke Posyandu }\end{array}$ & f & \% \\
\hline Positif & 49 & 52,12 \\
Negatif & 45 & 47,88 \\
\hline
\end{tabular}

Tabel 2 di bawah menunjukkan jika dilihat berdasarkan dimensi persepsi, didapatkan data bahwa 62,76\% ibu mempunyai persepsi positif terhadap kerentanan penyakit; $54,25 \%$ ibu mempunyai persepsi positif terhadap keseriusan dampak jika anaknya tidak dibawa ke posyandu terhadap kesehatannya; $52,12 \%$ ibu mempunyai persepsi positif

Tabel 2 Distribusi Frekuensi Persepsi Ibu Per Domain dengan Perilaku Membawa Balita ke Posyandu ( $\mathbf{N}=94)$

\begin{tabular}{lccc}
\hline Dimensi Persepsi & Kategori & f & \% \\
\hline Pesepsi terhadap kerentanan & Positif & 59 & 62,76 \\
& Negatif & 35 & 37,24 \\
Persepsi terhadap keseriusan & Positif & 51 & 54,25 \\
Persepsi terhadap manfaat & Negatif & 43 & 45,75 \\
& Positif & 49 & 52,12 \\
Persepsi terhadap hambatan & Negatif & 45 & 77,88 \\
& Positif & 74 & 21,28 \\
Motivasi kesehatan & Negatif & 20 & 85,1 \\
\hline
\end{tabular}

Tabel 3 Distribusi Frekuensi Perilaku Ibu Membawa Balita ke Posyandu (N = 94)

\begin{tabular}{lcc}
\hline $\begin{array}{c}\text { Perilaku Ibu Membawa Balita ke } \\
\text { Posyandu }\end{array}$ & f & \% \\
\hline Rutin & 56 & 59,57 \\
Tidak Rutin & 38 & 40,43 \\
\hline
\end{tabular}

Tabel 4 Tabulasi Silang Hubungan antara Persepsi dengan Perilaku Ibu Membawa Balita ke Posyandu

\begin{tabular}{|c|c|c|c|c|c|c|}
\hline \multirow{3}{*}{ No } & \multirow{3}{*}{$\begin{array}{c}\text { Persepsi } \\
\text { berdasarkan } \\
\text { Teori Health } \\
\text { Belief Mode }\end{array}$} & \multicolumn{4}{|c|}{ Perilaku Ibu Membawa Balita ke Posyandu } & \multirow[t]{3}{*}{ Nilai $\rho$} \\
\hline & & \multicolumn{2}{|c|}{ Rutin } & \multicolumn{2}{|c|}{ Tidak Rutin } & \\
\hline & & $\mathbf{f}$ & $\%$ & $\mathbf{f}$ & $\%$ & \\
\hline 1 & Positif & 38 & 40,42 & 11 & 11,71 & 0.000 \\
\hline 2 & Negatif & 18 & 19,15 & 27 & 28,72 & \\
\hline
\end{tabular}


Dian Palupi Kusuma Wardani: Hubungan Persepsi dengan Perilaku Ibu

Tabel 5 Tabulasi Silang Hubungan antara Dimensi Persepsi berdasarkan Teori Health Belief Model dengan Perilaku Ibu Membawa Balita ke Posyandu

\begin{tabular}{|c|c|c|c|c|c|c|c|}
\hline \multirow{3}{*}{ No } & \multirow[t]{3}{*}{ Dimensi Persepsi } & \multicolumn{4}{|c|}{ Perilaku Membawa Balita ke Posyandu } & \multirow{3}{*}{ Nilai $\rho$} & \multirow{3}{*}{ Odds Ratic } \\
\hline & & \multicolumn{2}{|c|}{ Rutin } & \multicolumn{2}{|c|}{ Tidak Rutin } & & \\
\hline & & f & $\%$ & $f$ & $\%$ & & \\
\hline \multirow[t]{3}{*}{1} & Persepsi Kerentanan & & & & & 0.711 & 1,174 \\
\hline & Positif & 36 & 38,3 & 23 & 24,46 & & \\
\hline & Negatif & 20 & 21,28 & 15 & 15,96 & & \\
\hline \multirow[t]{3}{*}{2} & Persepsi Keseriusan & & & & & 0.018 & 2,760 \\
\hline & Positif & 36 & 38,3 & 15 & 15,96 & & \\
\hline & Negatif & 20 & 21,28 & 23 & 24,46 & & \\
\hline \multirow[t]{3}{*}{3} & Persepsi Manfaat & & & & & 0.043 & 2,370 \\
\hline & Positif & 34 & 36,17 & 15 & 15,95 & & \\
\hline & Negatif & 22 & 23,41 & 23 & 24,47 & & \\
\hline \multirow[t]{3}{*}{4} & Persepsi Hambatan & & & & & 0.012 & 3,640 \\
\hline & Positif & 49 & 52,13 & 25 & 26,6 & & \\
\hline & Negatif & 7 & 7,44 & 13 & 13,83 & & \\
\hline \multirow[t]{3}{*}{5} & Motivasi Kesehatan & & & & & & \\
\hline & Positif & 52 & 55,32 & 28 & 29,78 & 0.010 & 4,643 \\
\hline & Negatif & 4 & 4,26 & 10 & 10,64 & & \\
\hline
\end{tabular}

terhadap manfaat membawa balita ke posyandu; 78,72\% ibu mempunyai persepsi positif terhadap hambatan yang dirasakan; dan $85,1 \%$ ibu mempunyai persepsi positif terhadap motivasi kesehatan yang didapat dari dalam maupun dari luar.

Tabel 3 terlihat bahwa 59,57\% ibu rutin membawa balitanya ke Posyandu di Desa Cimekar. Tabel 4 menunjukkan 40,42\% ibu yang mempunyai persepsi positif memiliki perilaku positif dalam membawa balita ke posyandu dan terdapat hubungan antara persepsi dengan perilaku ibu membawa balita ke posyandu ( $p=0.000 ; \alpha=0.05)$ (tabel 4).

Hasil uji chi square menunjukkan bahwa persepsi terhadap keseriusan yang dirasakan $(\mathrm{p}=0.018)$, manfaat yang dirasakan $(\mathrm{p}=0.043)$, rintangan yang dirasakan $(\mathrm{p}=0.012)$, dan motivasi kesehatan yang dirasakan $(\mathrm{p}=0.010)$ berhubungan dengan perilaku ibu dalam membawa balitanya ke posyandu. Variabel persepsi kerentanan yang dirasakan $(\mathrm{p}=0.711)$ tidak berhubungan dengan perilaku ibu dalam membawa balitanya ke posyandu dengan nilai $\mathrm{p}>0.05$.

Hasil penelitian menunjukkan bahwa berdasarkan nilai odds ratio terdapat pengaruh dimensi persepsi berdasarkan teori Health Belief Model terhadap perilaku ibu membawa balita ke posyandu. Dimensi persepsi yang berpengaruh terhadap perilaku ibu adalah persepsi tentang motivasi kesehatan yang memiliki pengaruh cukup besar terhadap perilaku membawa balita ke posyandu $(p=0,010)$ (Tabel 5). Tabel 5 dapat dilihat, ibu yang memiliki persepsi motivasi positif memiliki kecenderungan untuk rutin membawa anak ke posyandu sebesar 4,643 atau 5 kali lebih besar dibandingkan dengan yang memiliki persepsi motivasi negatif.

\section{Pembahasan}

Health Belief Model (HBM) adalah teori yang paling umum digunakan dalam pendidikan kesehatan dan promosi kesehatan (Glanz, Rimer, \& Lewis, 2002 \& National Cancer Institute [NCI], 2003). Teori Health Belief Model yang dikembangkan oleh Rosenstock (1988), menekankan bahwa perilaku kesehatan ditentukan oleh keyakinan pribadi atau persepsi tentang penyakit dan strategi yang tersedia untuk mengurangi terjadinya penyakit. Persepsi seseorang dipengaruhi oleh 
Dian Palupi Kusuma Wardani: Hubungan Persepsi dengan Perilaku Ibu

berbagai macam faktor yang memengaruhi perilaku kesehatan intrapersonal.

Teori Health Belief Model menekankan pada promosi peningkatan pelayanan kesehatan. Model ini ditindaklanjuti oleh Becker dan rekan pada 1970-an dan 1980an. Teori Health Belief Model didasarkan pada pemahaman bahwa seseorang akan mengambil tindakan yang akan berhubungan dengan kesehatan. Teori ini dituangkan dalam lima segi pemikiran dalam diri individu, yang memengaruhi upaya yang ada dalam diri individu untuk menentukan apa yang baik bagi dirinya, yaitu perceived susceptibility (kerentanan yang dirasakan/ diketahui), perceived severity (bahaya/ kesakitan yang dirasakan), perceived benefit of action (manfaat yang dirasakan dari tindakan yang diambil), perceived barrier to action (hambatan yang dirasakan akan tindakan yang diambil), dan cues to action (isyarat untuk melakukan tindakan). Hal tersebut dilakukan dengan tujuan self-efficacy atau upaya diri sendiri untuk menentukan apa yang baik bagi dirinya. Self-efficacy seseorang dalam melakukan suatu tindakan kesehatan menurut teori Health Belief Model dipengaruhi persepsi seseorang tentang kerentanan terhadap penyakit, potensi ancaman, motivasi untuk memperkecil kerentanan terhadap penyakit, adanya kepercayaan bahwa perubahan perilaku dapat memberikan keuntungan, penilaian individu terhadap perubahan yang ditawarkan, interaksi dengan petugas kesehatan yang merekomendasikan perubahan perilaku, dan pengalaman mencoba perilaku yang serupa.

Hasil penelitian ini menunjukkan bahwa $52,12 \%$ ibu memiliki persepsi positif bahwa membawa anaknya ke posyandu di Desa Cimekar berpengaruh positif terhadap kesehatan anaknya. Ibu menganggap bahwa posyandu merupakan tempat yang dapat dimanfaatkan ibu untuk memantau tumbuh kembang anak, menambah informasi tentang bagaimana menjaga dan merawat kesehatan anak, dan ibu menganggap penting keberadaan posyandu.

Dalam hal perilaku ibu membawa balita ke posyandu, berdasarkan penelitian ini didapatkan data bahwa 59,57\% ibu rutin membawa anak ke posyandu setiap bulan. Ibu juga pernah mendapatkan penyuluhan kesehatan (60,53\%). Penelitian serupa yang dilakukan Nofianti (2012), menemukan bahwa proporsi ibu balita yang memiliki perilaku baik dalam pemanfaatan posyandu untuk memantau pertumbuhan dan perkembangan anaknya adalah sebanyak $41 \%$ dan hasil penelitian Silaen (2011), menyatakan bahwa ibu yang memanfaatkan posyandu dengan baik sebesar 39\%. Selain itu, penelitian Tri (2007) menunjukkan rutinitas balita yang datang ke posyandu setiap bulan sebanyak 32,8\%. Sedangkan hasil penelitian Yuryanti (2010), menunjukkan bahwa perilaku kunjungan ibu balita ke posyandu sebesar $47 \%$. Keadaan ini menunjukkan bahwa meskipun lokasi penelitian berbeda, namun tingkat partisipasi mayarakat dalam menimbang anak balita ke posyandu tidak jauh berbeda dan tetap dibawah target nasional sebesar 85\%. Menurut hasil penelitian Nofianti (2012), faktor yang berhubungan secara bermakna dengan perilaku pemanfaatan posyandu oleh ibu balita adalah umur ibu, pekerjaan ibu, umur balita, urutan kelahiran balita, dan kepemilikan KMS.

Rendahnya cakupan penimbangan balita ke posyandu menunjukkan bahwa perilaku masyarakat dalam bidang kesehatan, khususnya dalam memantau pertumbuhan dan perkembangan balita masih rendah dan belum dianggap sebagai hal yang prioritas untuk dilakukan. Teori Health Behavior Model ini menekankan bahwa perilaku kesehatan ditentukan oleh keyakinan pribadi atau persepsi tentang penyakit dan strategi yang tersedia untuk mengurangi terjadinya penyakit.

Berdasarkan dimensi Health Belief Model, dimensi persepsi yang berpengaruh terhadap perilaku ibu dalam penelitian ini adalah persepsi ibu terhadap keseriusan, persepsi ibu akan manfaat posyandu, persepsi ibu terhadap hambatan, dan persepsi ibu dalam motivasi. Dimensi persepsi kerentanan tidak memiliki hubungan dengan perilaku ibu dalam membawa anak ke posyandu. Hal ini sejalan dengan penelitian yang dilakukan oleh Ary, Arsyad, \& Rismayanti (2014) dan Hayati, Sudiana, \& Kristiawati (2014). Penelitian Ary, Arsyad, \& Rismayanti (2014), menyatakan bahwa terdapat hubungan yang bermakna antara persepsi manfaat yang dirasakan 
Dian Palupi Kusuma Wardani: Hubungan Persepsi dengan Perilaku Ibu

serta rintangan yang dirasakan dengan status imunisasi balita. Penelitian Hayati, Sudiana, \& Kristiawati (2014), menunjukkan bahwa terdapat hubungan antara persepsi kerentanan orang tua, persepsi keseriusan orang tua, persepsi manfaat dan hambatan orang tua terhadap status gizi balita.

Dimensi persepsi ancaman keseriusan ibu merupakan persepsi ibu mengenai keseriusan atau dampak yang akan terjadi ketika ibu tidak membawa balita ke posyandu. Ibu menganggap bahwa membawa balita ke posyandu itu penting untuk menghindari dampak kesehatan yang tidak diinginkan, misalnya balita menjadi sakit. Hasil penelitian ini sejalan dengan penelitian yang dilakukan oleh Yenita (2011) yang menunjukkan bahwa persepsi individu akan keseriusan penyakit atau ancaman penyakit yang akan didapat ketika tidak melakukan tindakan kesehatan menjadi pendorong utama dalam melakukan tindakan kesehatan. Penelitian Yenita (2011), menunjukkan bahwa persepsi negatif ibu tentang keseriusan persalinan akan mendorong ibu dalam melakukan persalinan bukan oleh tenaga kesehatan.

Hasil penelitian ini juga sesuai dengan penelitian Fibriana (2013), dalam teori Health Belief Model (Rosenstock), yang menyatakan bahwa dalam melakukan tindakan dalam mencegah terjadinya suatu penyakit maupun mencari pengobatan dipengaruhi oleh persepsi terhadap keseriusan yang mungkin dirasakan apabila menderita suatu penyakit. Persepsi ini merupakan pandangan individu tentang beratnya penyakit yang diderita. Pandangan ini mendorong seseorang untuk mencari pengobatan atas penyakit yang dideritanya. Keseriusan ini ditambah dengan akibat dari suatu penyakit, misalnya kematian, pengurangan fungsi fisik dan mental, kecacatan, dan dampaknya terhadap kehidupan sosial.

Hasil penelitian ini juga menunjukkan bahwa persepsi ibu tentang manfaat posyandu berhubungan dengan perilaku ibu dalam membawa balita ke posyandu. Persepsi ibu akan manfaat (perceived benefit) menurut Rosenstrock berarti bahwa tindakan individu untuk mencari pengobatan dan pencegahan penyakit didorong oleh manfaat tindakan tersebut untuk pengobatan atau pencegahan penyakit. Pada penelitian ini, persepsi ibu terhadap manfaat posyandu mendorong ibu untuk datang rutin membawa balitanya ke posyandu. Manfaat posyandu yang dipersepsikan ibu, diantaranya bahwa membawa balita ke posyandu bermanfaat untuk mencegah gizi kurang, mendapatkan makanan tambahan, serta memantau pertumbuhan dan perkembangan anak.

Seseorang akan cenderung untuk menerapkan perilaku sehat ketika ia merasa perilaku tersebut bermanfaat untuk meningkatkan kesehatannya. Penelitian Ary, dkk., (2014), menunjukkan bahwa ibu akan membawa anak balitanya ke posyandu apabila ibu merasa tindakan tersebut bermanfaat dan sebaliknya. Persentase ibu yang tidak membawa balitanya ke posyandu terlihat masih tinggi karena ibu tidak merasakan manfaat dari posyandu tersebut.

Hasil penelitian menunjukkan bahwa persepsi tentang hambatan yang dirasakan akan tindakan yang diambil berhubungan dengan perilaku ibu dalam membawa balita ke posyandu. Rintangan dirasakan ibu adalah hambatan yang dialami ketika ibu hendak mengambil keputusan membawa balitanya ke posyandu. Hambatan tersebut dapat terdiri dari jarak, biaya, pengambilan keputusan dalam keluarga, norma/budaya, dan hambatan lainnya. Ada banyak rintangan yang harus dilalui seseorang untuk dapat melakukan suatu tindakan kesehatan, dan kebanyakan rintangan tersebut datang karena seseorang mengevaluasi halangan terhadap perilaku baru yang dilakukan. Sebelum mengadopsi perilaku, seseorang harus percaya bahwa besarnya rintangan yang dialami ketika melakukan tindakan pencegahan lebih kecil daripada konsekuensi atau tindakan lamanya (Hayden, 2010).

Penelitian ini menunjukkan bahwa dimensi persepsi motivasi (cues to action) ibu berhubungan dengan perilaku ibu membawa balita ke posyandu. Persepsi motivasi menurut Rosenstrock (1988) adalah bahwa tindakan kesehatan individu dicetuskan oleh motivasi seseorang, baik motivasi internal maupun eksternal. Motivasi internal atau isyarat internal (internal cues), yaitu motivasi untuk bertindak yang berasal dalam diri individu. Motivasi internal ibu untuk membawa anak ke posyandu diantaranya karena ibu merasakan adanya 
Dian Palupi Kusuma Wardani: Hubungan Persepsi dengan Perilaku Ibu

isyarat (cues) terhadap kesehatan anaknya, misalnya gejala yang dirasakan pada anaknya (demam, panas, nafsu makan anak menurun, berat badan menurun, berat badan tidak naik, dan lain-lain). Motivasi eksternal atau isyarat eksternal yaitu motivasi atau isyarat untuk bertindak yang berasal dari interaksi interpersonal, seperti media massa, pesan, nasihat, dan anjuran atau konsultasi dengan tenaga kesehatan. Motivasi eksternal yang dimiliki ibu untuk membawa anak ke posyandu didorong oleh pesan kesehatan yang ibu dapatkan pada saat penyuluhan kesehatan oleh petugas kesehatan, ibu membaca poster dan iklan di televisi tentang pentingnya posyandu, serta pengalaman sesama ibu tentang manfaat yang didapat jika ibu membawa balita ke posyandu.

Penelitian Yuryanti (2010), terdapat hubungan yang bermakna antara motivasi ibu balita dengan perilaku kunjungan ibu balita ke posyandu. Hal ini juga dikemukakan oleh Soni (2007), yang menemukan bahwa terdapat hubungan antara motivasi dengan keaktifan kader dalam mendorong ibu untuk membawa balitanya ke posyandu.

Persepsi ibu tentang kerentanan (perceived suspectibility) pada penelitian ini tidak berhubungan dengan perilaku ibu untuk membawa anak ke posyandu. Persepsi kerentanan artinya individu merasa bahwa ia rentan (susceptible) terhadap suatu penyakit yang akan mendorong individu untuk melakukan tindakan kesehatan. Kerentanan merupakan penilaian subjektif bagi setiap individu. Penelitian Hayati, dkk., (2014), menunjukkan bahwa kerentanan ini dapat dipengaruhi oleh beberapa hal yaitu faktor umur, penghasilan, etnis, dan pengetahuan seseorang. Pada penelitian ini, ibu tidak memersepsikan bahwa balitanya rentan terhadap suatu penyakit tertentu. Hasil penelitian ini tidak sejalan dengan penelitian Fibriana (2013); Hayati, dkk., (2014); dan Ary, dkk., (2014). Penelitian Fibriana (2013), menunjukkan bahwa seorang individu melakukan pemeriksaan HIV/ AIDS, karena individu tersebut memersepsikan dirinya rentan terhadap penyakit tersebut. Adapun penelitian Ary, dkk., (2014), menunjukkan bahwa ibu yang merasa anaknya berisiko terkena penyakit yang dapat dicegah dengan imunisasi melakukan tindakan pencegahan dengan vaksinasi. Penelitian Hayati, dkk., (2014) menunjukkan bahwa persepsi kerentanan orang tua tentang kemungkinan terkena suatu permasalahan gizi pada balitanya akan memengaruhi perilaku orang tua dalam melakukan pencegahan atau mencari pengobatan.

Penelitian ini menunjukkan bahwa hal tersebut tidak terjadi pada perilaku ibu dalam membawa balita ke posyandu. Menurut penelitian Astinah, dkk., (2013), agar seseorang bertindak untuk mengobati atau mencegah penyakitnya maka ia harus merasakan bahwa ia rentan terhadap penyakit tersebut. Apabila seseorang merasa tidak rentan terhadap penyakit tersebut, maka perlu diberikan rangsangan yang lebih intensif agar dia juga mencetuskan respon yang diinginkan yaitu membawa balitanya secara rutin ke posyandu. Kerentanan yang dirasakan rendah terhadap suatu penyakit dapat disebabkan karena minimnya pengetahuan tentang bahaya penyakit tersebut. Sehingga apabila dikaitkan dengan penelitian ini, ibu yang tidak membawa balitanya sama sekali atau tidak secara rutin membawa balitanya ke posyandu memiliki pengetahuan yang rendah terhadap risiko penyakit tersebut, sehingga sangat penting untuk sosialisasi pentingnya membawa balita secara rutin ke posyandu.

Penelitian Pamungkas (2009), menemukan bahwa terdapat hubungan antara pengetahuan ibu balita dengan perilaku kunjungan ibu ke posyandu. Secara keseluruhan ibu yang mempunyai tingkat pengetahuan baik, ratarata mempunyai tingkat perilaku berkunjung ke posyandu yang baik. Penelitian lain oleh Tricia (2008), yang menyatakan bahwa terdapat hubungan antara pengetahuan ibu dengan tindakan ibu untuk membawa anaknya ke posyandu.

Hasil penelitian ini menunjukkan bahwa dimensi persepsi yang paling berhubungan dengan perilaku ibu dalam membawa balita ke posyandu adalah persepsi motivasi dengan nilai odds ratio sebesar 4,64 kali, yang menunjukkan bahwa ibu yang memiliki persepsi motivasi yang positif akan mendorong sebesar 4,64 kali lebih besar untuk membawa anaknya ke posyandu dibandingkan dengan ibu yang memiliki persepsi motivasi negatif. Perawat komunitas dan tenaga kesehatan lain harus lebih 
Dian Palupi Kusuma Wardani: Hubungan Persepsi dengan Perilaku Ibu

meningkatkan motivasi ibu karena terbukti menjadi pendorong utama dalam perilaku ibu dalam membawa anak ke posyandu. Upaya untuk meningkatkan motivasi ibu dapat dilakukan melalui kegiatan penyuluhan oleh kader, konsultasi kader, sosialisasi posyandu melalui poster ataupun melalui dukungan sebaya (peer support).

\section{Simpulan}

Terdapat hubungan antara persepsi dengan perilaku ibu membawa balita ke posyandu. Sebanyak 52,12\% ibu mempunyai persepsi positif dalam membawa balita ke posyandu dan sebanyak 59,57\% ibu rutin membawa balitanya ke posyandu. Dimensi persepsi motivasi merupakan dimensi persepsi paling besar yang mendorong ibu untuk membawa balita ke posyandu dengan nilai odds ratio sebesar 4,64; yang menunjukkan bahwa ibu yang memiliki persepsi motivasi yang positif akan mendorong sebesar 4,64 kali lebih besar untuk membawa anaknya ke posyandu dibandingkan dengan ibu yang memiliki persepsi motivasi negatif. Perawat komunitas dan tenaga kesehatan lain harus lebih meningkatkan motivasi ibu karena terbukti menjadi pendorong utama dalam perilaku ibu dalam membawa anak ke posyandu. Upaya untuk meningkatkan motivasi ibu dapat dilakukan melalui kegiatan penyuluhan oleh kader, konsultasi kader, sosialisasi posyandu melalui poster ataupun melalui dukungan sebaya (peer support).

\section{Daftar Pustaka}

Ary, D., Arsyad, D. S., \& Rismayanti. (2014). Pemanfaatan Imunisasi di Kelurahan Pampang Kecamatan Panakkukang Kota Makassar (Pendekatan Health Belief Model). Makassar: Universitas Hasanuddin.

Astinah, Hasbullah, S., \& Muzakkir, H. (2013). Faktor-faktor yang Memengaruhi Kepatuhan Ibu pada Pemberian Imunisasi Dasar di Posyandu Teratai 11B di Wilayah Kerja Puskesmas Tamamaung Makassar. Jurnal STIKES Nani Hasanuddin Makassar, 2(6), 8-15. ISSN: 2302-1721.

Bappenas. (2014). Laporan Pencapaian
Tujuan Pembangunan Millenium MDG's di Indonesia tahun 2014. Jakarta: Bappenas.

Dinas Kesehatan Kabupaten Bandung. (2013). Laporan Tahunan Dinas Kesehatan Kabupaten Bandung. Soreang: Dinas Kesehatan Kabupaten Bandung.

Farida, H. (2012). Hubungan Pendidikan, Pekerjaan, Pengetahuan, dan Kepuasan Ibu terhadap Posyandu dengan Frekuensi Kunjungan Balita ke Posyandu di Puskesmas. Jurnal Kedokteran Lambung Mangkurat, 1(4).

Fibriana, A. I. (2013). Keikutsertaan Pelanggan Wanita Pekerja Seks dalam Voluntary Conseling and Testing (VCT). Jurnal Kesehatan Masyarakat, 8(2).

Glanz, K., Rimer, B. K., \& Lewis, F. M. (2002). Health Behavior and Health Education; Theory, Research and Practice. University of Michigan.

Hayati, M., Sudiana, K. I., \& Kristiawati. (2014). Analisis Faktor Orang Tua terhadap Status Gizi Balita Pendekatan Teori Health Belief Model. Surabaya: Universitas Airlangga.

Hayden, J. A. (2010). Health Belief Theory. New Jersey: Jones and Bartlett Publisher.

Kemenkes RI. (2012). Profil Kesehatan Indonesia 2011. Jakarta: Kementrian Kesehatan Republik Indonesia.

Laporan Puskesmas Cinunuk. (2013). Laporan Tahunan Puskesmas Cinunuk. Bandung: Puskesmas Cinunuk.

Keputusan Menteri Kesehatan RI Nomor 1457/ Menkes/ SK/ X/ 2003. (2003). Keputusan Menkes RI tentang Standard Pelayanan Minimal Bidang Kesehatan di Kabupaten/ Kota. Jakarta: Kementrian Kesehatan Republik Indonesia.

National Cancer Institute. (2003). Health Behavior Construct: Theory, Measurement \& Research. Diperoleh melalui: www.cancer. gov. 
Dian Palupi Kusuma Wardani: Hubungan Persepsi dengan Perilaku Ibu

Nofianti, S. (2012). Faktor-faktor yang berhubungan dengan Perilaku Pemanfaatan Posyandu oleh Ibu Balita di Wilayah Kerja Puskesmas Maek Kabupaten Lima Puluh Kota Tahun 2012. Skripsi. Depok: Fakultas Kesehatan Masyarakat, Program Studi Sarjana Kesehatan Masyarakat, Universitas Indonesia.

Notoatmodjo, S. (2007). Promosi Kesehatan dan Ilmu Perilaku. Jakarta: Rineka Cipta.

Pamungkas, L. (2009). Hubungan antara Faktor Pengetahuan, Sikap, dan Kepercayaan dengan Perilaku Ibu Berkunjung ke Posyandu di Kelurahan Grabag Kecamatan Grabag Kabupaten Magelang. Diperoleh melalui: http://eprints.undip.ac.id.

Rachmania, H. K. (2010). Faktor-faktor yang berhubungan dengan Kunjungan Ibu Balita dalam Kegiatan Posyandu (Studi di Desa Lumingser Kecamatan Adiwerna Kabupaten Tegal Tahun 2010). Diperoleh melalui: http:// digilib.unimus.ac.id (diakses pada 15 Maret 2014, 19.00).

Rosentrock, I. M., Stretcher, V. J., \& Becker, M. H. (1988). Social Learning Theory and the Health Belief Model. Health Educ, 15(2), 175-83.

Silaen, H. E. (2011). Hubungan Pengetahuan Ibu, Pemanfaatan Posyandu, dan Faktor Lainnya terhadap Status Gizi Balita di Wilayah Kerja Puskesmas Bromo Medan Tahun 2011. Depok: Fakultas Kesehatan Masyarakat Universitas Indonesia.

Sirait, L. M., \& Sarumpaet, S. (2013). Hubungan Komponen Health Belief Model (HBM) dengan Penggunaan Kondom pada Anak Buah Kapal (ABK) di Pelabuhan Belawan. Jurnal Pre Cure, 1(1).

Soni, D. (2007). Faktor-faktor yang berhubungan dengan Keaktifan Kader
Posyandu di Kota Pariaman Tahun 2007. Depok: Fakultas Kesehatan Masyarakat Universitas Indonesia.

Tri, L. D. (2008). Faktor-faktor yang berhubungan dengan Rutinitas Ibu Membawa Batita ke Posyandu di Desa Banda dan Merak, Kecamatan Balaraja, Kabupaten Tangerang Tahun 2007. Depok: Fakultas Kesehatan Masyarakat Universitas Indonesia.

Tricia, Y. (2008). Faktor-fakor yang berhubungan dengan Tindakan Ibu untuk Membawa Anak Balitanya ke Posyandu di Kecamatan Palas Kabupaten Lampung Selatan Tahun 2008. Depok: Fakultas Kesehatan Masyarakat Universitas Indonesia.

Trihono. (2005). Arrimes Manajemen Puskesmas Berbasis Paradigma Sehat. Yogjakarta: Sagung Seto.

UNICEF. (2014). Sekitar 35 Juta Balita Masih Berisiko Jika Target Angka Kematian Anak Tidak Tercapai. Jakarta: UNICEF Indonesia.

Yenita, S. (2011). Faktor Determinan Pemilihan Tenaga Penolong Persalinan di Wilayah Kerja Puskesmas Desa Baru Kabupaten Pasaman Barat. Repository Universitas Andalas.

Yuryanti. (2010). Faktor-faktor yang berhubungan dengan Perilaku Kunjungan Ibu Balita ke Posyandu di Kelurahan Muka Kuning Wilayah Kerja Puskesmas Sei Pancur Kota Batam Tahun 2010. Depok: Fakultas Kesehatan Masyarakat Universitas Indonesia. 